\title{
KARAKTERISTIK TAPAK, BENIH DAN BIBIT 11 POPULASI JABON PUTIH (Anthocepalus cadamba Miq.)
}

\author{
Site, Seed and Seedling Characteristics of the 11 Populations of \\ White Jabon (Anthocepalus cadamba Miq.) \\ Dede J. Sudrajat ${ }^{1}$, Yulianti Bramasto ${ }^{1}$, Iskandar Z. Siregar ${ }^{2}$, Ulfah J. Siregar ${ }^{2}$, \\ Irdika Mansur ${ }^{2}$, dan/and Nurul Khumaida ${ }^{3}$ \\ 'Balai Penelitian Teknologi Perbenihan Tanaman Hutan Bogor \\ Jl. Pakuan Ciheuleut PO BOX. 105 Bogor \\ Telp./Faks.: 0251-8327768 \\ ${ }^{2}$ Departemen Silvikultur, Fakultas Kehutanan, Institut Pertanian Bogor \\ Jl. Lingkar Kampus IPB, Dramaga-Bogor \\ ${ }^{3}$ Departemen Agronomi dan Holtikultura, Fakultas Pertanian, \\ Jl. Lingkar Kampus IPB, Darmaga-Bogor
}

Naskah masuk : 16 Juli 2013; Naskah diterima : 6 Februari 2014

\begin{abstract}
White jabon (Anthocephalus cadamba Miq.) is a potential fast-growing tree species which naturally distributed in most of Indonesia islands. The study aims to assess the characteristic of site and morphophysiological variation of seeds and seedlings of white jabon. The seeds were collected from 11 natural populations, i.e. Sumatera (3 populations), Java (2 populations), Nusa Kambangan (1 population), Kalimantan (2 populations), Sulawesi (2 populations), and Sumbawa (1 population). The research revealed that white jabon naturally grows at elevations ranging from 23-628 $\mathrm{m}$ asl, $\mathrm{pH}$ 4.4-6.7 and in the low to high soil fertility condition. Significant differences were found for all fruits, seeds and seedling characters except for radicle length. The fruit morphological characters showed significant positive correlations with several seedling growth characters. Seed length was positively correlated with mean time of germination and radicle length. Most of the seed and seedling characters were not significant correlation with geo-climate variables of the populations. Percentage of genotypic coefficient of variance for all of the parameters was higher than percentage of environmental coefficient of variation.
\end{abstract}

Keywords: Anthocephalus cadamda, fruit, seed and seedling, variation, morphophysiology

\begin{abstract}
ABSTRAK
Jabon putih (Anthocephalus cadamba Miq.) merupakan salah satu jenis tanaman hutan cepat tumbuh potensial yang tersebar secara alami di sebagian besar pulau-pulau Indonesia. Penelitian ini bertujuan untuk mengkaji karakteristik tapak dan keragaman morfofisiologi benih dan bibit jabon putih. Benih dikumpulkan dari 11 populasi alami, yaitu di Sumatera (3 populasi), Jawa (2 populasi), Nusa Kambangan (1 populasi), Kalimantan (2 populasi), Sulawesi (2 populasi) dan Sumbawa (1 populasi). Hasil penelitian menunjukkan bahwa jabon putih mempunyai sebaran tempat tumbuh yang sangar luas dan kisaran kondisi tapak secara alami yang cukup beragam. Jenis ini mampu tumbuh baik pada kisaran ketinggian tempat 23-628 $\mathrm{m}$ dpl dengan kisaran $\mathrm{pH}$ tanah 4,4-6,7 dan tingkat kesuburan rendah hingga tinggi. Karakteristik morfofisiologi benih dan bibit berbeda nyata antar populasi, kecuali untuk karakter panjang radikula. Buah dengan ukuran dan berat yang lebih tinggi berkorelasi dengan pertumbuhan bibit yang lebih baik. Panjang benih berkorelasi dengan waktu rata-rata berkecambah dan panjang radikula. Korelasi juga terjadi antar karakter pada tingkat bibit. Sebagian besar karakter benih dan bibit yang diamati tidak berkorelasi dengan faktorfaktor geoklimat. Koefisien keragaman genotipe untuk semua parameter buah, benih, dan bibit ditemukan lebih tinggi daripada koefisien keragaman lingkungan.
\end{abstract}

Kata kunci : Anthocephalus cadamda, buah, benih dan bibit, keragaman, morfofisiologi 


\section{PENDAHULUAN}

Jabon putih [Anthocephalus cadamba Miq. (sinonim Anthocephalus shinensis (Lamk.), Neolamarkcia cadamba (Roxb.) Bosser, famili Rubiaceae)) merupakan jenis potensial asli Indonesia yang cepat tumbuh dan multiguna. Jabon putih dapat digunakan untuk kayu lapis, konstruksi, pulp, papan serat, papan partikel (Soerianegara \& Lemmens, 1993; Kartawinata 1994), dan bahan obat-obatan seperti penghilang sakit, radang, penurun demam (Modal et al., 2009), antimikroba (Acharyya et al., 2011) dan antibakteri (Mishra \& Siddique 2011). Menurut Wong (1989), jabon pertama kali dibudidayakan di Indonesia pada tahun 1933. Pada saat ini jabon sudah banyak ditanam dalam skala besar di beberapa daerah seperti Sumatera Utara, Riau dan Kalimantan Tengah dan juga telah banyak dibudidayakan oleh petani, terutama di Jawa dan Kalimantan Selatan (Kallio et al., 2011; Krisnawati et al., 2011).

Jabon putih dapat dikategorikan sebagai jenis tanaman yang tumbuh pada tahapan awal suksesi (Shukla \& Ramakrishnan, 1986) yang tumbuh baik pada tanah-tanah aluvial yang lembab dan umumnya dijumpai di hutan sekunder atau terdegradasi di sepanjang bantaran sungai dan daerah transisi antara daerah berawa, daerah yang tergenang air secara permanen maupun secara periodik (Phillips et al., 2002). Jenis ini dapat tumbuh pada berbagai jenis tanah, terutama pada tanah-tanah yang subur dan beraerasi baik (Soerianegara \& Lemmens, 1993).

Di Indonesia, jabon putih tersebar hampir di seluruh pulau, seperti Sumatera, Kalimantan, Jawa, Sulawesi, Nusa Tenggara, Maluku dan Papua (Martawijaya et al., 1989; Krisnawati et al., 2011). Teori evolusi menduga bahwa jenis dengan sebaran luas akan memiliki tingkat keragaman yang luas. Namun informasi keragaman tersebut masih sangat terbatas, termasuk informasi tapak dan morfofisiologi benih dan bibitnya. Penelitian ini akan menjawab apakah distribusi geografi dan kisaran tipe tapak populasi jabon putih yang beragam berasosiasi dengan keragaman morfofisiologi benih dan bibitnya sebagai informasi dasar untuk kegiatan pemuliaan tanaman jabon putih.

Studi perbedaan karakter buah dan benih antar populasi tanaman hutan telah banyak dilakukan pada jenis-jenis tanaman hutan seperti pada Pinus wallichiana di India (Rawat dan Bakshi 2011), Trigonobalanus doichangensis di China (Zheng et al., 2009), Cedrus deodara di Jammu dan Kashmir (Mughal dan Thapliyal, 2012) dan Senna siamea di Thailand (Takuathung et al., 2012). Keragaman geografis untuk karakteristik bibit juga telah diteliti diantaranya pada jenis Pinus strobus (Stephan 1974), Juglans nigra (Bey 1979) dan Picea asperata (Jiang-xun et al., 2009). Penelitian-penelitian tersebut menunjukkan adanya keragaman morfofisiologi benih dan bibit antar populasi yang diamati. Untuk jenis jabon putih, informasi tersebut belum tersedia. Tujuan penelitian ini adalah untuk mengkaji karakteristik tapak dan keragaman morfofisilogi benih dan bibit, dan untuk mengetahui faktorfaktor geoklimat dan genetik yang mengendalikan karakteristik morfofisiologi benih dan bibit jabon putih.

\section{METODOLOGI}

\section{A. Bahan}

Pengumpulan buah A. cadamba dilakukan di 11 populasi alami jabon putih (Gambar 1). Pengumpulan buah dilakukan selama 4 (empat) bulan dari bulan Mei hingga bulan Juni 2012 . Jumlah pohon induk setiap lokasi bervariasi dari 10-20 pohon. Untuk mendapatkan variasi genetik yang maksimum, pohon induk dipilih dengan jarak 50-100 m antar satu dengan pohon induk lainnya. Buah yang dikumpulkan dari setiap lokasi dibawa ke laboratorium benih Balai Penelitian Teknologi Perbenihan Tanaman Hutan Bogor. Sampel buah diambil dari setiap pohon induk dengan jumlah yang sama kemudian dicampur untuk setiap populasi. Benih diekstrak secara manual dengan metode ekstraksi basah (Bonner et al., 1994). 


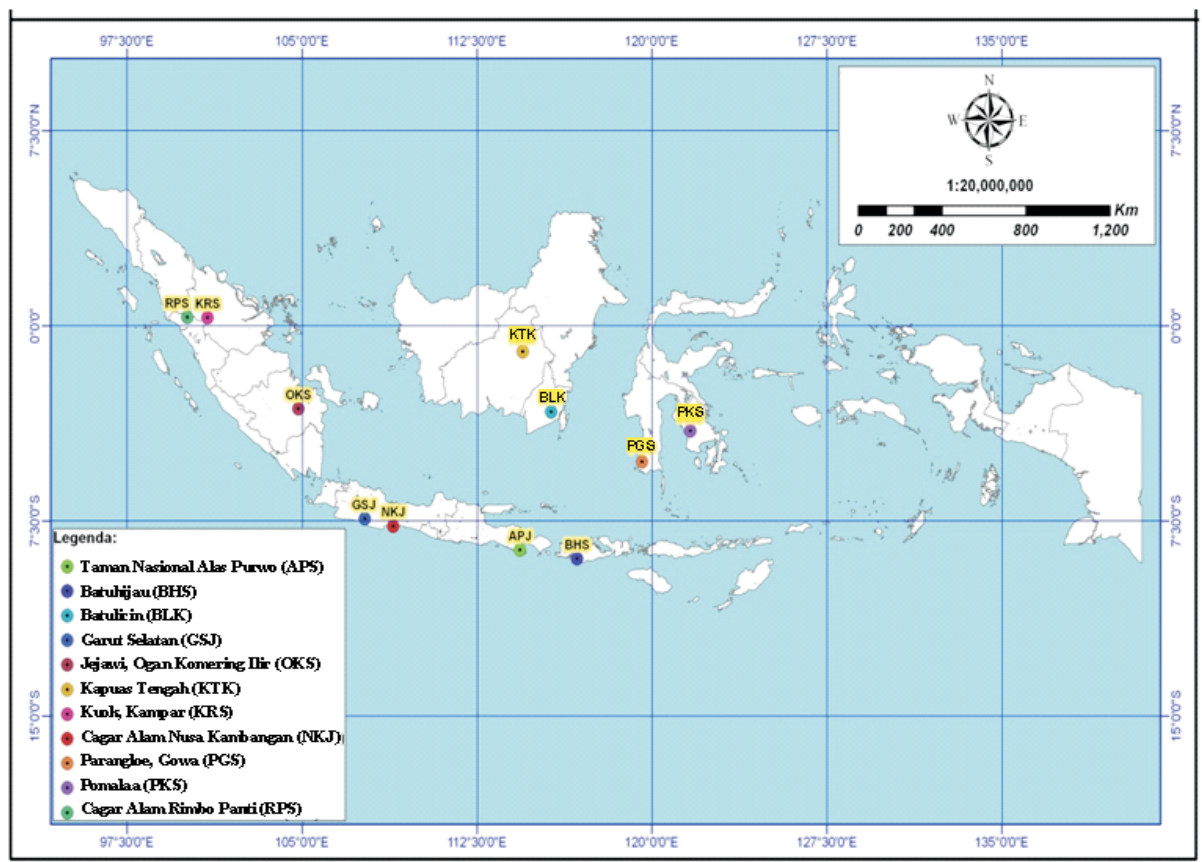

Gambar(Figure) 1. Distribusi geografik 11 populasi jabon putih yang diuji (Geographic distribution of the 11 investigated populations of whitejabon)

\section{B. Pengumpulan Data Lapangan}

Data lapangan yang dikumpulkan adalah letak geografis, curah hujan, suhu rata-rata tahunan dan ketinggian tempat. Pengambilan sampel tanah dilakukan secara komposit, di bawah setiap pohon induk yang dijadikan sampel pada kedalaman 10-20 $\mathrm{cm}$ dari permukaan tanah (Suganda et al., 2006). Contoh tanah dari setiap populasi dianalisis tingkat kesuburannya di Laboratorium Tanah dan Nutrisi, SeameoBiotrop (http://www.biotrop.org), Bogor.

\section{Pengukuran Karakteristik Buah dan Benih}

Karakteristik buah yang diukur adalah diameter buah dan berat buah. Diameter buah diukur dengan kaliper digital terhadap diameter terbesar dan diameter terkecil buah, sedangkan berat buah diukur dengan timbangan digital. Karakteristik benih yang diukur adalah panjang benih, lebar benih, dan berat 1.000 butir benih. Dari setiap kelompok benih yang mewakili 11 populasi, 100 butir benih komposit diukur panjang dan lebarnya dengan menggunakan mikroskop elektron (Zeis discovery V.8 stereo). Berat benih ditentukan dengan 8 ulangan, masingmasing ulangan sebanyak 100 butir benih dan kemudian ditransformasi ke dalam berat 1.000 butir benih (ISTA, 2010).

\section{Uji Perkecambahan dan Karakteristik Semai}

Studi perkecambahan benih dilakukan di rumah kaca pada kondisi suhu $29-34{ }^{\circ} \mathrm{C}$. Sebanyak 100 butir benih dengan 6 (enam) ulangan ditabur pada media campuran pasir dan tanah halus $(1: 1 \mathrm{v} / \mathrm{v})$, kemudian disungkup plastik transparan untuk mempertahankan kelembaban media tabur. Sebuah benih dinyatakan berkecambah bila telah muncul sepasang daun secara sempurna. Perkecambahan benih diukur setiap hari selama 20 hari. Data yang dicatat dan dihitung adalah daya berkecambah, kecepatan berkecambah (Maguire, 1962), dan rata-rata waktu perkecambahan (Edmond dan Drapala, 1958). Panjang hipokotil dan radikula diukur pada akhir perkecambahan. Indeks vigor (total panjang kecambah dikali persentase berkecambah) dihitung berdasarkan Bhattacharya et al. (1991).

\section{E. Pengukuran Karakteristik Bibit}

Benih disemaikan di rumah kaca dengan menggunakan bak kecambah. Bibit disapih ke polibag berukuran $12 \mathrm{~cm} \times 15 \mathrm{~cm}$ yang diisi media campuran topsoil, kompos pupuk kandang, dan arang sekam $(3: 2: 1 \mathrm{v} / \mathrm{v})$. Bibit-bibit tersebut disusun dalam bentuk rancangan acak berblok dengan 8 (delapan) ulangan. Setiap ulangan terdiri dari 25 bibit yang disusun bujur 
sangkar ( 5 bibit x 5 bibit). Setelah bibit berumur 3 (tiga) bulan, sebanyak 9 (sembilan) bibit per ulangan yang berada di bagian tengah kelompok bibit diukur tinggi, diameter, jumlah daun, panjang daun, lebar daun dan indeks kekokohan bibit. Panjang dan lebar daun diukur dengan mengukur 2 (dua) pasang daun bagian atas yang telah berkembang sempurna. Indeks kekokohan bibit diukur dengan membagi tinggi bibit $(\mathrm{cm})$ dengan diameter ( $\mathrm{mm})$.

Berat kering akar dan tajuk dihitung dengan membagi bibit menjadi 2 (dua) bagian, yaitu bagian akar dan bagian tajuk (batang dan daun), kemudian dikeringkan dalam oven selama 48 jam pada suhu $70^{\circ} \mathrm{C}$. Berat kering total dihitung dengan menjumlahkan berat kering akar, batang dan daun. Rasio akar pucuk (RAP) diukur berdasarkan berat kering akar dibagi berat kering pucuk.

Pengamatan terhadap kerapatan struktur stomata daun dilakukan pada siang hari dengan menghitung jumlah stomata per satuan luas bidang pengamatan. Pencetakan stomata dilakukan pada daun bagian atas yang telah berkembang sempurna dengan menggunakan cat kuku pada permukaan atas dan bawah daun (Sanchez et al., 2011). Cat kuku dioleskan pada permukaan daun hingga kering, kemudian cetakan tersebut diambil dan diletakkan pada kaca obyektif mikroskop dengan pembesaran 40 kali dan ditutup dengan cover glass. Kerapatan stomata (jumlah stomata per millimeter) dihitung dengan membagi jumlah stomata dengan luas bidang pengamatan $\left(0,19625 \mathrm{~mm}^{2}\right)$. Kandungan klorofil diukur pada daun kedua dari apical. Klorofil diekstraks dari 3 (tiga) sampel bibit dengan berat sampel 0,025 g daun segar. Pengukuran dilakukan dengan UV/visible spectrophotometer (UV1201, Shimadzu Corporation, Tokyo, Japan) pada absorbansi 663 dan 647 (Lichtenthaler, 1987).

\section{F. Analisis Data}

Karakteristik tapak dianalisis secara deskriptif. Rancangan acak lengkap digunakan untuk menguji perbedaan karakteristik buah, benih dan bibit, sedangkan rancangan acak blok digunakan untuk menguji karakteristik bibit di persemaian. Data dianalisis dengan program ANOVA menggunakan SPSS 21 dan Duncan Multiple Range Test (DMRT) untuk menguji signifikasi perbedaan antara karakteristik daun, buah, benih, dan bibit. Sebelumnya, data persentase (daya berkecambah) ditransformasi arcsine $\sqrt{ } \mathrm{x}$ untuk meningkatkan kenormalan data. Korelasi sederhana (Pearson) digunakan untuk menemukan hubungan antar sifat-sifat buah, benih dan bibit dengan faktor iklim dan geografis (curah hujan tahunan, suhu rata-rata tahunan, ketinggian tempat, lintang dan bujur).

Untuk membandingkan besarnya keragaman yang disebabkan oleh populasi dan lingkungan dan pengaruh bukan genetik lainnya, koefisien keragaman populasi (KVG) dan keragaman lingkungan dan bukan genetik lainnya (KVL) dihitung untuk karakter benih dan bibit dengan menggunakan keragaman populasi (Vg), keragaman lingkungan ( $\mathrm{Vl}$ ) dan rata-rata dengan rumus sebagai berikut:

$\mathrm{KVG}=(\mathrm{Vg})^{1 / 2} /$ Mean

dan

$\mathrm{KVL}=(\mathrm{Vl})^{1 / 2} /$ Mean $)$

Untuk menentukan besarnya keragaman populasi berkontribusi terhadap keragaman total, heritabilitas dalam arti luas (broad sense heritability) dihitung sebagai berikut :

$\mathrm{H}^{2}=\mathrm{Vg}(\mathrm{Vg}+\mathrm{Vl})$

(Zeng etal., 2009).

Kemajuan genetik (GA) se-bagai persentase dari asumsi seleksi 5\% dari ge-notipe superior (diferensiasi seleksi $(\mathrm{K})=2,06$ ) dihitung dengan rumus:

$\mathrm{GA}=\mathrm{K} \cdot \mathrm{H}^{2} \cdot \sqrt{ } \mathrm{Vp}$

$\mathrm{GA}($ sebagai $\%$ dari rata-rata $)=(\mathrm{GA} / \mathrm{X}) \times 100 \ldots . .(5)$

dimana:

$\mathrm{Vp}=$ keragaman fenotipa, $\mathrm{X}=$ rata-rata parameter (Johnson et al., 1995).

\section{HASIL DAN PEMBAHASAN}

\section{A. Hasil}

\section{Karakteristik tapak}

Kondisi tempat tumbuh 11 populasi yang diamati sangat beragam dengan ketinggian tempat tumbuh berada pada kisaran 23-628 $\mathrm{m}$ di atas permukaan laut (m dpl). Kisaran curah hujan 1.500-3.102 $\mathrm{mm} /$ tahun dengan suhu tahunan 24,4-29 ${ }^{\circ} \mathrm{C}$. Karakteristik tanah dicirikan dengan kisaran $\mathrm{pH}$ 4,4 (sangat masam) - 6,7 (netral), Corganik 1,1 (rendah) - 6,7 (sangat tinggi); $\mathrm{N}$ total 0,13 (rendah) $-0,57$ (tinggi); $\mathrm{C} / \mathrm{N}$ ratio 7,3 (rendah) - 17,6 (tinggi); P tersedia 2,47 (sangat rendah) - 334,18 (sangat tinggi); K 0,15 (rendah) 4,00 (sedang); Ca 1,76 (sangat rendah) - 29,65 (sangat tinggi); dan $\mathrm{Mg}$ 0,57 (rendah) - 11,41 
(sangat tinggi). Kapasitas tukar kation berada pada kisaran 6,84 (rendah) - 49,33 (tinggi), sedangkan kejenuhan basa berkisar antara 33,1 (rendah)-100 (sangat tinggi) (Tabel 1).

\section{Karakteristik benih dan bibit}

Populasi berpengaruh nyata dan sangat nyata terhadap semua parameter morfofisiologi benih dan bibit, kecuali untuk panjang radikula tidak dipengaruhi oleh perbedaan populasi. Perbedaan antar populasi juga terjadi pada semua parameter morfofisiologi benih dan bibit, kecuali panjang radikula. Secara keseluruhan dari studi keragaman ini menunjukkan bahwa populasi PKS memiliki nilai tertinggi untuk 9 (sembilan) karakter, yaitu pada berat buah, berat 1.000 butir benih, daya berkecambah, kecepatan berkecambah, indeks vigor, tinggi bibit, berat kering tajuk, berat kering akar dan berat kering total bibit, dan disusul oleh populasi PGS yang memiliki nilai tertinggi pada 6 (enam) karakter, yaitu diameter terbesar buah, diameter terkecil buah, berat buah, indeks vigor, jumlah daun dan panjang daun. Populasi KTK dan BLK hampir sama pada semua parameter mempunyai nilai terendah, seperti diameter terbesar buah, diameter terkecil buah, berat buah, berat 1.000 benih, tinggi bibit, diameter bibit, panjang daun, lebar daun, luas daun, kerapatan stomata, klorofil A, klorofil B, dan berat kering bibit(Tabel 2).

Tabel(Table) 1. Karakteristik geoklimat dan hasil analisis tanah 11 populasi jabon putih (Geo-climate characteristics and result of soil analysis of the 11 populations of white jabon)

\begin{tabular}{|c|c|c|c|c|c|c|c|c|c|c|c|}
\hline \multirow{2}{*}{ Parameter (Parameters) } & \multicolumn{11}{|c|}{ Populasi (Populations) } \\
\hline & RPS & KRS & OKJ & GSJ & NKJ & APJ & KTK & BLK & PGS & PKS & BHS \\
\hline $\begin{array}{l}\text { Ketinggian tempat (altitude) } \\
(\mathrm{m} \mathrm{dpl}) \text { ( } \mathrm{m} \text { as } l)\end{array}$ & 294 & 50 & 23 & 628 & 40 & 33 & 147 & 47 & 132 & 210 & 53 \\
\hline $\begin{array}{l}\text { Curah hujan (rainfall) } \\
\text { (mm/tahun) (mm/year) }\end{array}$ & 3.102 & 3.000 & 2.500 & 2.589 & 2.500 & 1.500 & 2.347 & 2.979 & 1.825 & 1.788 & 2.297 \\
\hline $\begin{array}{l}\text { Suhu rata-rata tahunan (mean } \\
\text { annual temperature) }\left({ }^{\circ} \mathrm{C}\right)\end{array}$ & 24,4 & 26,5 & 27,1 & 27 & 28 & 28,5 & 28,7 & 28,5 & 27,3 & 28,0 & 29,0 \\
\hline \multicolumn{12}{|l|}{$\begin{array}{l}\text { Kimia tanah }(\text { soil } \\
\text { characteristics }):\end{array}$} \\
\hline$-\mathrm{pH} \mathrm{H}_{2} \mathrm{O}$ & 5,1 & 4,4 & 4,7 & 5,1 & 6,7 & 6,0 & 4,4 & 4,6 & 5,5 & 6,1 & 6,4 \\
\hline - C organik (\%) & 1,87 & 1,10 & 2,82 & 2,25 & 4,95 & 3,16 & 4,75 & 6,70 & 2,12 & 4,60 & 1,64 \\
\hline$-\mathrm{N}$ total $(\%)$ & 0,20 & 0,13 & 0,35 & 0,31 & 0,47 & 0,18 & 0,36 & 0,57 & 0,25 & 0,38 & 0,17 \\
\hline -Rasio C/N & 9,4 & 8,5 & 8,1 & 7,3 & 10,5 & 17,6 & 13,2 & 11,8 & 8,5 & 12,1 & 9,6 \\
\hline -P tersedia (ppm) & 15,18 & 5,47 & 6,86 & 2,47 & 10,94 & 334,18 & 6,44 & 10,55 & 46,84 & 15,82 & 90,28 \\
\hline$-\mathrm{Ca}(\mathrm{cmol} / \mathrm{kg})$ & 7,03 & 1,76 & 13,16 & 9,26 & 29,65 & 20,15 & 2,09 & 28,83 & 17,24 & 10,33 & 13,78 \\
\hline$-\mathrm{Mg}(\mathrm{cmol} / \mathrm{kg})$ & 3,29 & 1,20 & 5,20 & 6,26 & 8,37 & 11,41 & 0,57 & 6,33 & 8,55 & 6,42 & 5,86 \\
\hline$-\mathrm{K}(\mathrm{cmol} / \mathrm{kg})$ & 2,10 & 0,15 & 2,44 & 0,98 & 1,46 & 4,00 & 2,35 & 1,51 & 3,42 & 1,58 & 2,78 \\
\hline$-\mathrm{Na}(\mathrm{cmol} / \mathrm{kg})$ & 0,28 & 4,79 & 0,40 & 0,27 & 1,98 & 2,06 & 0,37 & 0,28 & 0,36 & 0,32 & 0,37 \\
\hline $\begin{array}{l}\text { - Kapasitas tukar kation (cation } \\
\text { exchange capacity) (cmol/kg) }\end{array}$ & 6,84 & 13,25 & 23,59 & 19,16 & 49,33 & 37,98 & 16,27 & 28,21 & 34,42 & 9,35 & 13,09 \\
\hline $\begin{array}{l}\text { - Kejenuhan basa (base } \\
\text { saturation) }(\%)\end{array}$ & 100 & 59,60 & 90 & 88 & 84 & 99 & 33,1 & 100 & 86 & 100 & 100 \\
\hline$-\mathrm{Al}^{3-}(\mathrm{me} / 100 \mathrm{~g})$ & 0,11 & 5,15 & 0,10 & 3,52 & 0,00 & 0,11 & 1,46 & 1,00 & 0,12 & 0,00 & 0,11 \\
\hline$-\mathrm{H}^{+}(\mathrm{me} / 100 \mathrm{~g})$ & 0,05 & 0,09 & 0,04 & 0,06 & 0,00 & 0,04 & 2,70 & 0,00 & 0,05 & 0,14 & 0,04 \\
\hline \multicolumn{12}{|l|}{ Tekstur (Texture): } \\
\hline - Pasir (sand) (\%) & 78,4 & 15,6 & 14,4 & 26,2 & 3,8 & 19,0 & 5,2 & 6,2 & 51,5 & 70,7 & 52,4 \\
\hline - Debu $(d u s t)(\%)$ & 6,2 & 30,0 & 33,5 & 21,6 & 18,4 & 20,8 & 46,8 & 46,8 & 24,0 & 14,8 & 27,2 \\
\hline - Liat (clay) $(\%)$ & 15,4 & 54,4 & 52,1 & 52,2 & 77,8 & 60,2 & 47,0 & 47,0 & 24,5 & 14,4 & 20,4 \\
\hline
\end{tabular}

Keterangan (Remarks): RPS= Cagar alam Rimbopanti, Pasaman, Sumatera Barat; KRS= Kampar, Riau; OKS= Jejawi, Ogan Komering Ilir, Sumatera Selatan; GSJ= Garut Selatan, Jawa Barat; NKJ= Pulau Nusa Kambangan, Jawa Tengah; APJ= Taman Nasional Alas Purwo, Jawa Timur; KTK= Kapuas Tengah, Kalimantan Tengah; BLK= Batulicin, Kalimantan Selatan; PGS= Parangloe, Gowa, Sulawesi Selatan; $\mathrm{PKS}=$ Pomalaa, Sulawesi Tenggara; BHS= Batuhijau, Sumbawa 


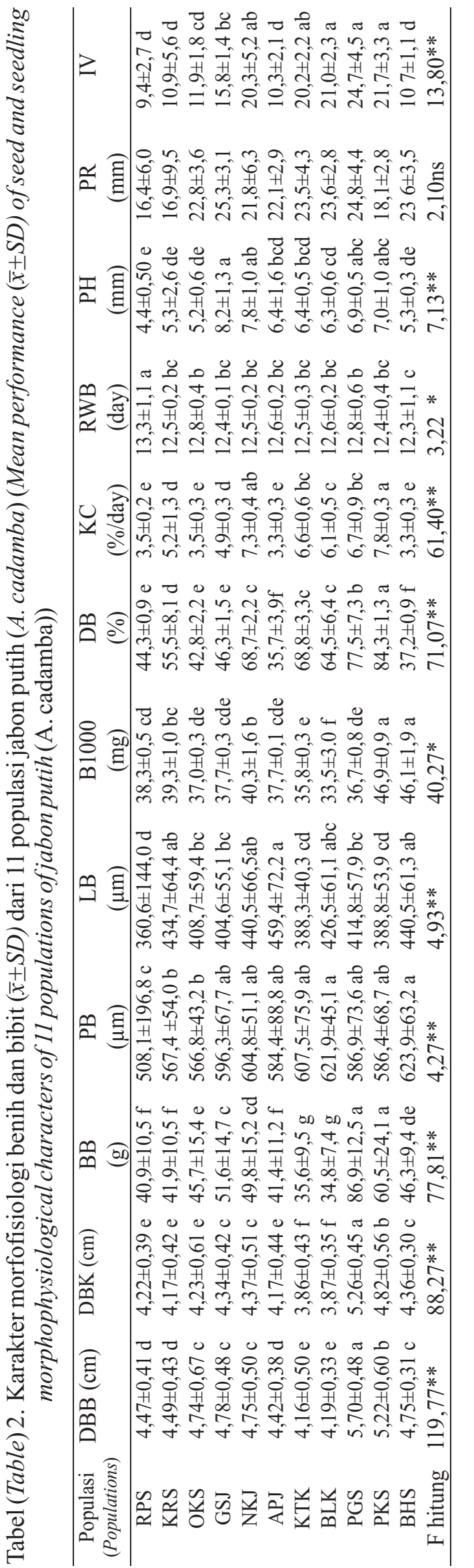

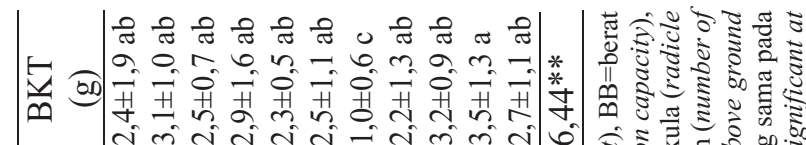

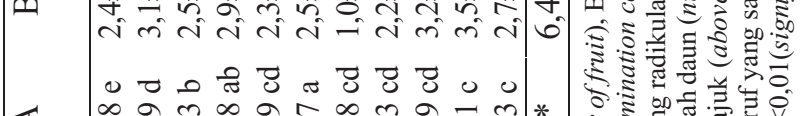

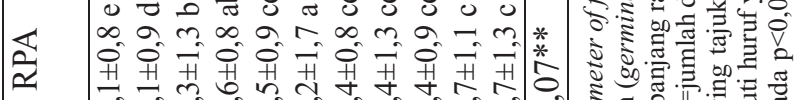

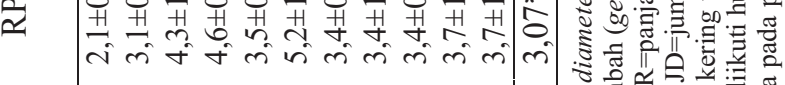

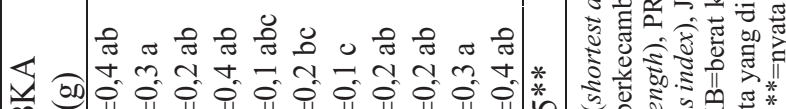

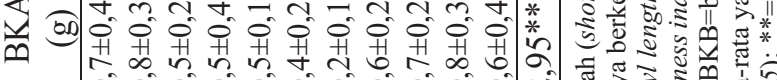

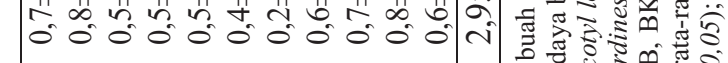

유 주 유

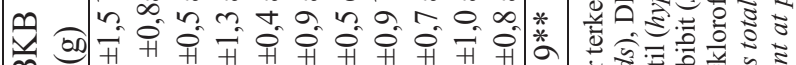

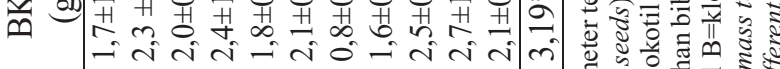

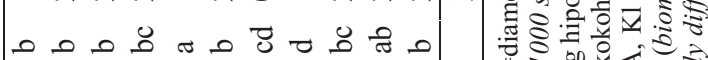

ص

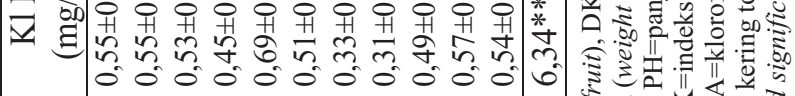

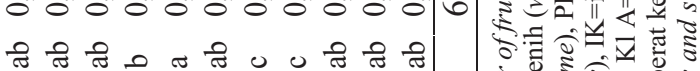

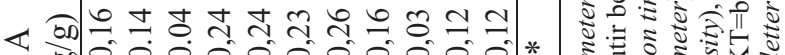

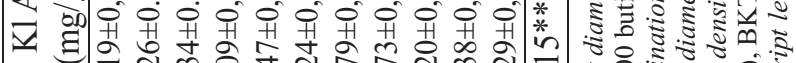

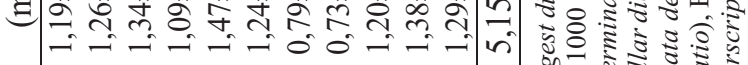

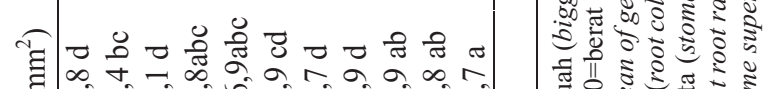

थ

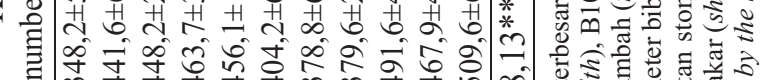

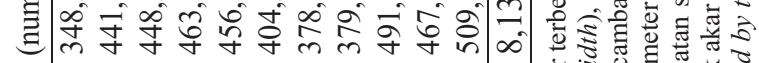

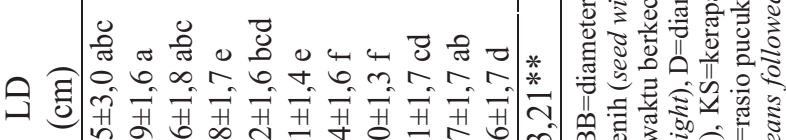

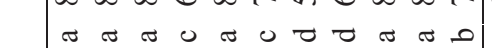

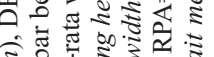

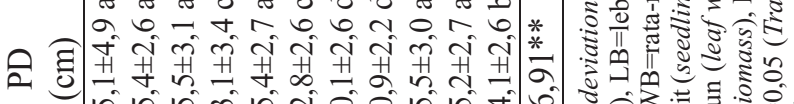

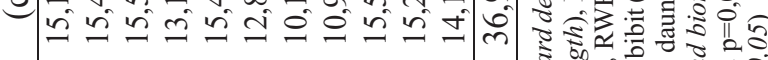

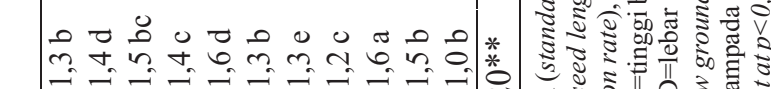

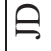

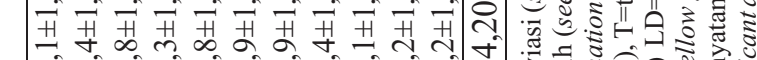

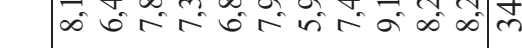

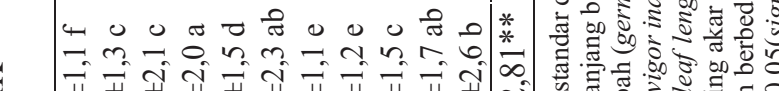

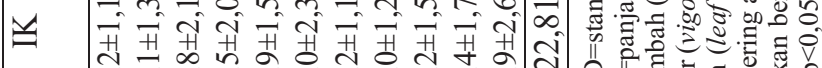

fं

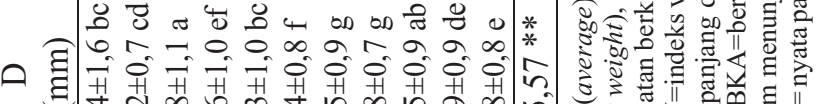

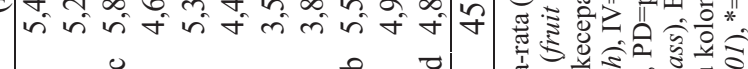

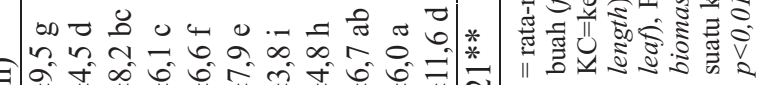

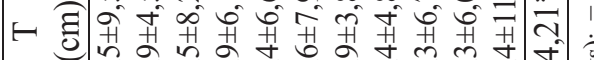

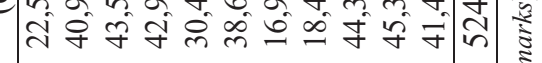

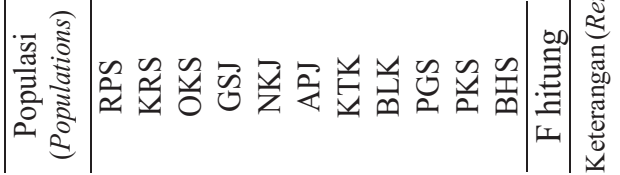




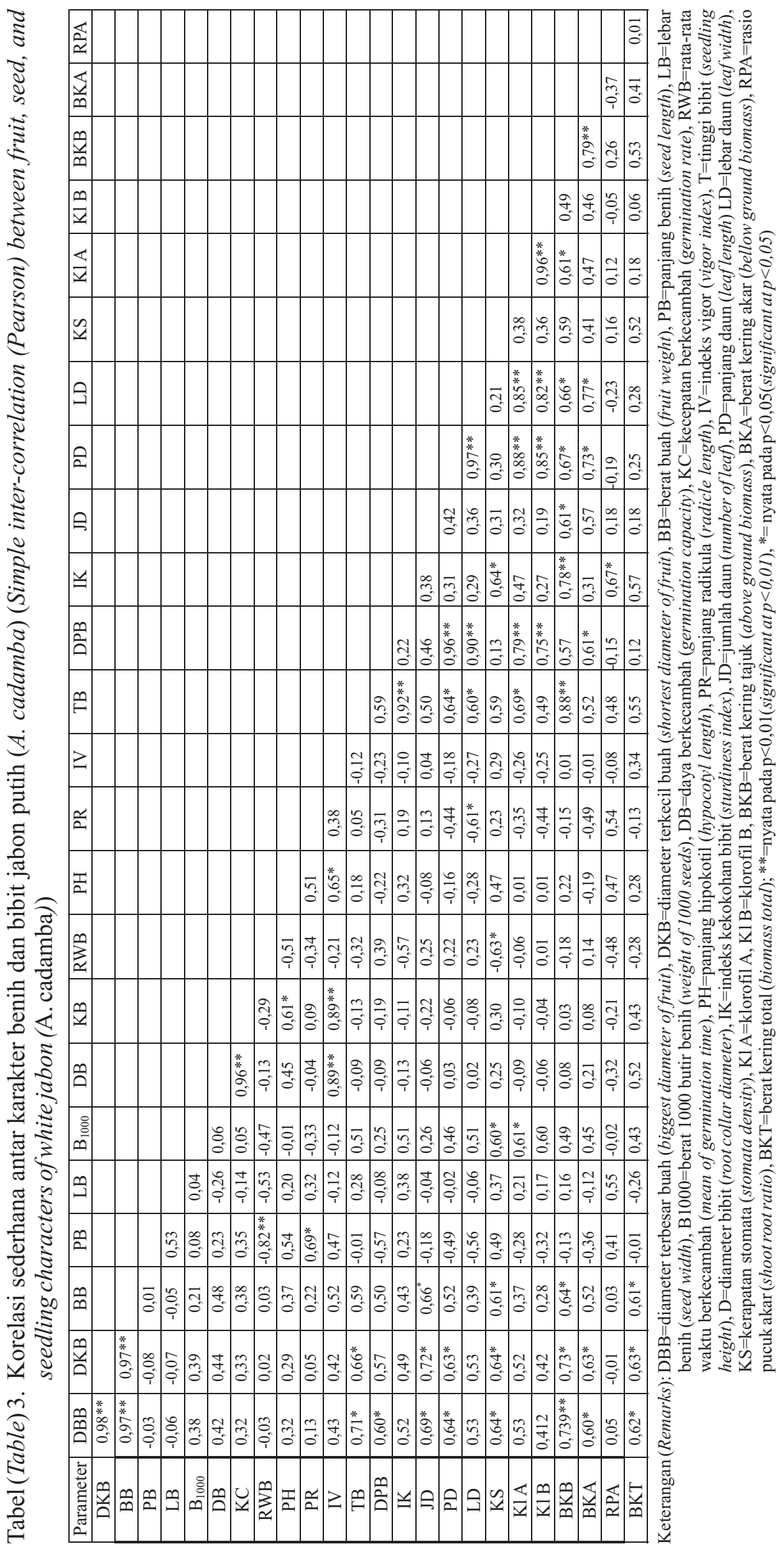




\section{Korelasi antar karakter morfofisiologi be- nih, bibit dan faktor geoklimat}

Korelasi positif nyata ditunjukkan antara karakter diameter dan berat buah dengan beberapa parameter pertumbuhan bibit. Panjang benih berkorelasi negatif dengan rata-rata waktu berkecambah (koefisien korelasi atau $r=-0,820$ ) dan berkorelasi positif dengan panjang radikula $(0,650)$. Makin panjang benih makin pendek waktu yang diperlukan untuk berkecambah dan makin panjang radikula semai. Korelasi antar karakter morfofisiologi benih dan bibit lainnya dapat dilihat pada Tabel 3.

Korelasi sederhana antara karakter morfofisiologi benih dan bibit dengan faktor geoklimat menunjukkan bahwa letak lintang berkorelasi positif dengan lebar benih $(r=0,615)$, sedangkan letak bujur berkorelasi dengan panjang benih $(\mathrm{r}=$ $0,646)$ dan indeks vigor $(r=0,638)$. Korelasi lainnya ditunjukkan oleh suhu rata-rata yang berkorelasi positif dengan panjang benih $(\mathrm{r}=$
0,917), namun berkorelasi negatif dengan ratarata waktu berkecambah $(r=-0,775)$. Sebagian besar karakteristik buah, benih dan bibit tidak berkorelasi nyata dengan faktor-faktor geoklimat (Tabel 4.).

Karakter buah, benih dan bibit dengan faktor geoklimat pada beberapa sifat menunjukkan adanya korelasi. Letak lintang berkorelasi positif dengan lebar benih $(r=0,615)$ dan rasio pucuk akar $(\mathrm{r}=0,690)$, sedangkan letak bujur bekorelasi dengan panjang benih $(\mathrm{r}=0,646)$ dan indeks vigor $(r=0,638)$. Suhu rata-rata tahunan berkorelasi positif dengan panjang benih $(r=0,917)$ dan berkorelasi negatif dengan rata-rata waktu berkecambah (Tabel 4). Regresi linear antar karakter buah, benih dan bibit yang berkorelasi dengan faktor geoklimat disajikan pada Gambar 2. Secara umum sebagian besar karakteristik daun, buah, benih dan bibit tidak berkorelasi nyata dengan faktor-faktor geoklimat.

Tabel(Table) 4. Korelasi sederhana antar karakter benih dan bibit dan faktor geoklimat (Simple correlation (Pearson) between characters studied and geo-climate factors)

\begin{tabular}{|c|c|c|c|c|c|}
\hline $\begin{array}{l}\text { Parameter } \\
\text { (Parameters) }\end{array}$ & $\begin{array}{l}\text { Lintang } \\
\text { (Latitute) }\end{array}$ & $\begin{array}{c}\text { Bujur } \\
\text { (Longitute) }\end{array}$ & $\begin{array}{l}\text { Ketinggian } \\
\text { tempat } \\
\text { (Altitude) }\end{array}$ & $\begin{array}{l}\text { Curah hujan } \\
\text { (Rainfall) }\end{array}$ & $\begin{array}{l}\text { Suhu rata-rata (Mean } \\
\text { annual temperature) }\end{array}$ \\
\hline DBB & 0,304 & 0,401 & 0,137 & $-0,498$ & $-0,070$ \\
\hline DKB & 0,281 & 0,419 & 0,125 & $-0,526$ & $-0,100$ \\
\hline BB & 0,268 & 0,432 & 0,142 & $-0,503$ & $-0,057$ \\
\hline PB & 0,553 & $0,646^{*}$ & $-0,195$ & $-0,280$ & $0,917 * *$ \\
\hline LB & $0,615^{*}$ & 0,178 & $-0,523$ & $-0,295$ & 0,578 \\
\hline $\mathrm{B}_{1000}$ & 0,318 & 0,277 & $-0,012$ & $-0,315$ & 0,159 \\
\hline DB & $-0,226$ & 0,491 & $-0,045$ & $-0,176$ & 0,171 \\
\hline $\mathrm{KC}$ & $-0,106$ & 0,458 & 0,013 & $-0,151$ & 0,265 \\
\hline RWB & $-0,533$ & $-0,473$ & 0,044 & 0,313 & $-0,775^{* *}$ \\
\hline PH & 0,546 & 0,412 & 0,394 & $-0,374$ & 0,400 \\
\hline PR & 0,585 & 0,446 & 0,098 & $-0,302$ & 0,582 \\
\hline IV & 0,056 & $0,638^{*}$ & 0,032 & $-0,266$ & 0,368 \\
\hline TB & 0,433 & 0,131 & 0,100 & $-0,480$ & 0,012 \\
\hline DPB & $-0,010$ & $-0,383$ & $-0,059$ & 0,015 & $-0,572$ \\
\hline IK & 0,563 & 0,311 & 0,177 & $-0,592$ & 0,272 \\
\hline JD & 0,368 & 0,388 & 0,073 & $-0,446$ & $-0,128$ \\
\hline PD & 0,022 & $-0,291$ & $-0,080$ & $-0,030$ & $-0,496$ \\
\hline LD & $-0,114$ & $-0,327$ & $-0,124$ & 0,014 & $-0,526$ \\
\hline KS & 0,586 & 0,478 & 0,122 & $-0,398$ & 0,349 \\
\hline $\mathrm{Kl}$ A & 0,336 & $-0,151$ & $-0,145$ & $-0,292$ & $-0,192$ \\
\hline Kl B & 0,264 & $-0,258$ & $-0,139$ & $-0,130$ & $-0,272$ \\
\hline BKB & 0,327 & 0,146 & 0,214 & $-0,338$ & $-0,169$ \\
\hline BKA & $-0,130$ & $-0,026$ & 0,066 & 0,087 & $-0,449$ \\
\hline RPA & $0,690^{*}$ & 0,280 & 0,051 & $-0,507$ & 0,520 \\
\hline BKT & $-0,108$ & 0,370 & 0,282 & $-0,431$ & 0,010 \\
\hline
\end{tabular}

Keterangan $\left(\right.$ Remarks) : ${ }^{* *}=$ nyata pada $\mathrm{p}<0,01$ (significant at $\left.\mathrm{p}<0,01\right),{ }^{*}=$ nyata pada $\mathrm{p}<0,05$ (significant at $\mathrm{p}<0,05$ ) 

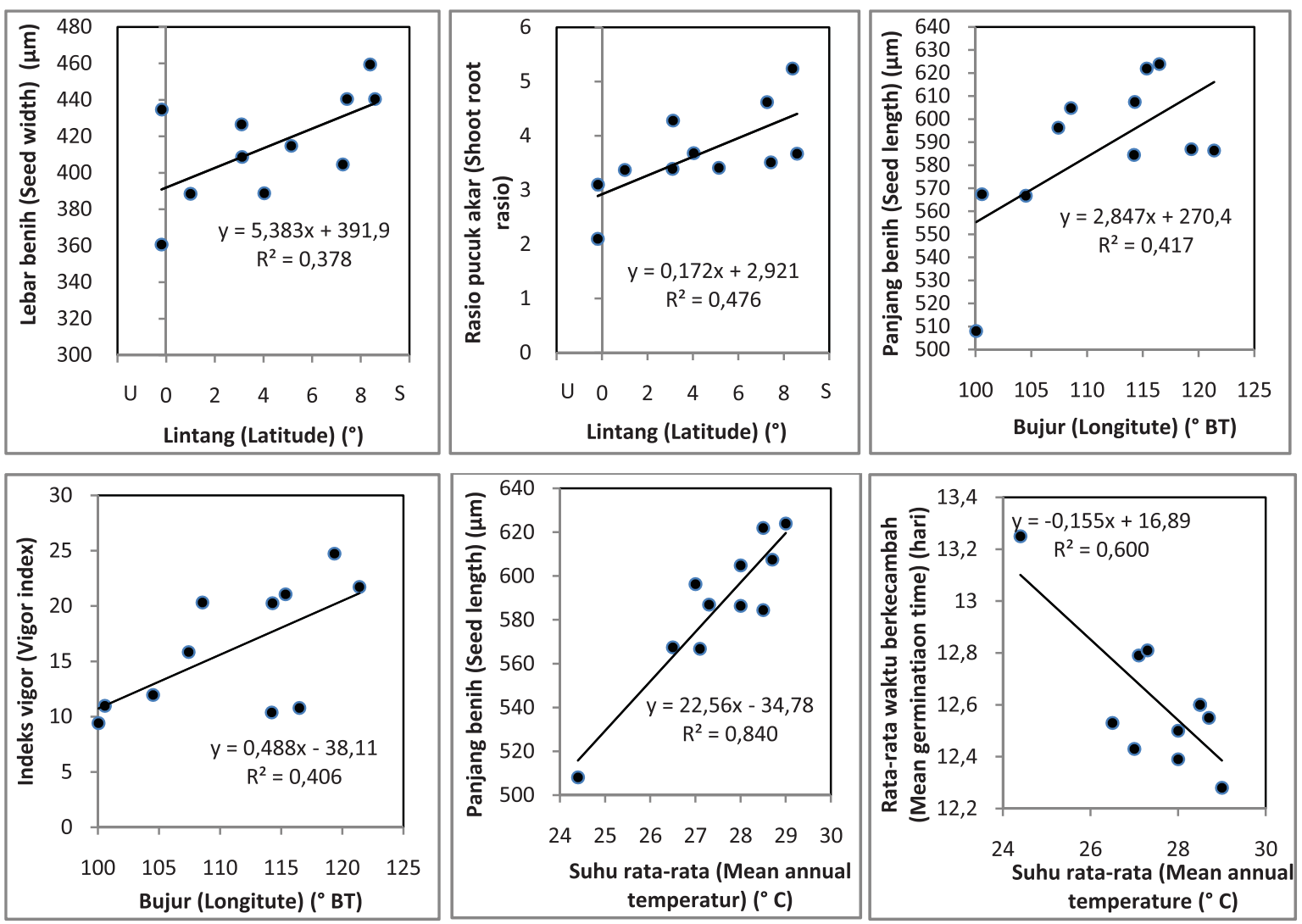

Gambar(Figure)2. Karakter morfofisiologi benih dan bibit dalam hubungannya dengan letak lintang, bujur, dan suhu rata-rata tahunan (Morphophysiological characters of seed and seedling in the correlation with latitude, longitude, and mean annual temperature)

\section{Koefisien keragaman}

Sebagian besar koefisien keragaman disebabkan oleh keragaman populasi atau genetik. Koefisien keragaman genetik pada semua parameter berkisar antara 51,25-95,82\%. Koefisien keragaman lingkungan tertinggi dihasilkan rata-rata waktu berkecambah (40,00\%), panjang radikula $(48,75 \%)$, berat kering tajuk $(40,32)$, berat kering akar $(41,69 \%)$, dan berat kering total $(40,97 \%)$. Dugaan heritabilitas dalam arti luas berkisar dari $52 \%$ untuk panjang radikula hingga $99 \%$ untuk berat buah, tinggi bibit dan indeks kekokohan, sedangkan kemajuan genetik berkisar antara 8,68\% untuk panjang benih dan $157,09 \%$ untuk tinggi bibit (Tabel 5).

\section{B. Pembahasan}

\section{Karakteristik tapak}

Kondisi tapak 11 populasi jabon yang tersebar di Sumatera, Jawa, Nusa Kambangan, Kalimantan, Sumbawa, dan Sulawesi sangat beragam yang umumnya berada pada daerah-daerah yang di bawah $200 \mathrm{~m}$ dpl, kecuali populasi Garut
Selatan, Rimbopanti, dan Pomalaa yang berada pada ketinggian tempat $628 \mathrm{~m} \mathrm{dpl,} 294 \mathrm{~m}$ dpl, dan $210 \mathrm{~m}$ dpl. Menurut Martawijaya et al. (1989), jabon putih tumbuh pada ketinggian 0-1.000 m dpl dengan rata-rata curah hujan tahunan berkisar $1.500-5.000 \mathrm{~mm}$.

Dilihat dari tingkat kesuburannya, tapak pada populasi-populasi yang diamati cukup beragam, sebagian besar $\mathrm{pH}$ tanah dikategorikan sangat rendah $(\mathrm{pH}<5,5)$ dan rendah $(\mathrm{pH}<6,5)$, kecuali untuk populasi Nusa Kambangan (NKJ) yang berada pada $\mathrm{pH}$ sedang ( $\mathrm{pH}$ 6,7). Kandungan $\mathrm{C}$ organik berada pada kondisi rendah (1,00-2,00 $\%$ ) hingga sangat tinggi $(>5,00 \%)$ dan $\mathrm{N}$ total berada pada tingkatan rendah $(0,10-0,20 \%)$ hingga tinggi $(0,51-0,75 \%)$. Kapasitas tukar kation dikategorikan rendah hingga sangat tinggi dan kejenuhan basa sangat tinggi (Pusat Penelitian Tanah, 1983). Secara umum, jabon dapat tumbuh pada kondisi tanah asam dengan tingkat kesuburan rendah hingga tinggi. Keragaman tapak ini memberi indikasi bahwa jabon putih memiliki kisaran lingkungan tumbuh dan daya adaptasi yang cukup luas. 


\section{Karakteristik benih dan bibit}

Analisis ragam dan nilai rata-rata karakter buah, benih dan bibit jabon menunjukkan perbedaan antar populasi yang nyata pada tingkat kepercayaan $5 \%$, kecuali untuk panjang radikula. Kondisi ini memberi indikasi adanya keragaman karakteristik benih dan bibit antar populasi. Populasi PKS mempunyai karakter morfofisiologi benih dan bibit (berat dan perkecambahan benih serta pertumbuhan bibit) yang lebih baik dibandingkan populasi lainnya, sedangkan populasi BLK dan KTK mempunyai karakter morfofisiologi benih dan bibit yang lebih rendah. Keragaman morfofisiologi dari populasi berbeda telah diteliti juga pada beberapa jenis, seperti Pinus roxburghii (Sagawal 1984; Seghal 1984; Mukherjee 2005), Picea aspera (Jian-xun et al., 2005), Trigonobalanus doichangensis (Zheng et al., 2009), Pinus wallichiana (Rawat \& Bakshi 2011), Senna siamea (Takuathung et al., 2012) dan Cedrus deodara (Mughal \& Thapliyal, 2012). Keragaman ukuran buah ini dipengaruhi oleh perbedaan lokasi, pohon dalam suatu lokasi dan antar buah di dalam pohon tersebut yang dikontrol secara bersamaan oleh faktor genetik dan lingkungan, seperti iklim, tanah, posisi dalam tajuk dan kerapatannya (Lester, 1969). Keragaman dalam perkecambahan antar sumber benih juga dilaporkan pada jenis Acacia mangium (Salazar 1989), Pinus roxburghii (Roy et al., 2004), dan Pinus wallichiana (Rawat \& Bakshi 2011).

Pengaruh lingkungan makin berkurang ketika benih dan bibit ditumbuhkan pada kondisi yang sama di rumah kaca dan persemaian, namun keragaman parameter perkecambahan dan pertumbuhan bibit jabon putih masih tinggi. Menurut Rawat \& Bakshi (2011), ketika benih dan bibit ditumbuhkan pada kondisi yang sama, sering menghasilkan pola pertumbuhan yang berbeda yang dapat diinterpretasikan sebagai pengaruh genetik karena pengaruh lingkungan dianggap nol. Perbedaan pada tingkat bibit antar populasi juga terjadi pada jenis Pinus roxburghii (Ghildiyal et al., 2009) dan Adansonia digitata (Sanchez et al., 2011). Sneizko \& Stewart (1989) berpendapat bahwa keragaman antar populasi dan di dalam populasi dalam karakter-karakter di persemaian merupakan faktor genetik yang penting di alam. Parameter perkecambahan benih dan pertumbuhan bibit tergantung dan dikontrol secara genetik, dipengaruhi lingkungan dan sifatsifat benih (Dunlop \& Barnett, 1984; Pathak et al., 1984). Kondisi ini menggambarkan adanya kombinasi kontrol genotipe dan lingkungan seperti iklim dan tanah.

\section{Korelasi antar karakter morfofisiologi be- nih, bibit dan faktor geoklimat}

Ukuran dan berat buah berkorelasi positif dengan beberapa parameter pertumbuhan bibit, seperti tinggi total, diameter, jumlah daun, panjang daun, kerapatan stomata daun berat kering tajuk, berat kering akar dan berat kering total bibit. Menurut Maheswari dan Konar (1971), ukuran dan berat buah yang lebih besar secara nyata dapat menghasilkan benih lebih banyak dengan kualitas yang lebih baik. Benih yang berkualitas baik akan mempunyai vigor bibit yang baik sehingga ukuran dan berat benih jabon yang besar seperti pada populasi PKS dan PGS (rata-rata diameter buah $>4,80 \mathrm{~cm}$ dan berat buah $>60 \mathrm{~g}$ ) menghasilkan pertumbuhan bibit yang lebih baik.

Panjang benih berkorelasi negatif dengan waktu rata-rata berkecambah. Benih-benih yang berukuran lebih panjang berkecambah lebih cepat, mempunyai radikula yang lebih panjang, dan berkembang sempurna yang diduga berhubungan dengan cadangan makanan endosperma yang lebih banyak (Kandya, 1978). Benih-benih yang lebih panjang juga mempunyai ukuran kotiledon yang lebih besar. Kotiledon secara fisiologis memainkan peran utama dalam perkecambahan, pertumbuhan dan perkembangan kecambah/ semai (Devagiri, 1978; dan Singh, 1998) sehingga benih jabon putih yang lebih panjang akan lebih cepat berkecambah. Cadangan makanan yang disimpan dalam endosperma atau kotiledon sangat penting selama proses perkecambahan dan pertumbuhan awal semai (Marshall \& Kozlowski, 1976). Keragaman ukuran benih disebabkan oleh kondisi internal (pohon induk, keturunan) dan eksternal (lingkungan) yang mempengaruhi proses perkembangan benih (Harper $e t$ al., 1970).

Beberapa faktor geoklimat juga berkorelasi dengan karakter morfofisiologi benih dan bibit. Ukuran lebar benih bertambah besar dengan bertambahnya derajat garis lintang ke arah Selatan. Besarnya ukuran benih dengan bertambahnya lintang ke arah Selatan diduga berhubungan dengan tingkat kesubaran tanah pada tapak-tapak di sebelah Selatan (Tabel 2). Populasi di bagian Selatan umumnya memiliki $\mathrm{pH}$ yang relatif lebih baik $(\mathrm{pH}>5,1)$ dibandingkan dengan populasi di bagian Utara yang umunya $\mathrm{pH}$ sangat rendah 
terutama populasi-populasi di Pulau Sumatera dan Kalimantan $(\mathrm{pH}<5,1)$. Dilihat dari tingkat kesuburan pun, tapak di populasi bagian Selatan (populasi GSJ, NKJ, APJ, dan BHS) relatif lebih baik khususnya unsure makro (N, $\mathrm{P}, \mathrm{K}, \mathrm{Ca}, \mathrm{Mg})$. $\mathrm{pH}$ dan tingkat kesuburan yang lebih baik diduga berdampak pada pertumbuhan dan perkembangan buah dan benih sehingga benih-benih dari tapak-tapak yang lebih subur berukuran lebih besar.

Benih jabon putih juga makin panjang dan memiliki vigor yang lebih baik dengan bertambahnya garis bujur ke arah Timur. Curah hujan yang tinggi pada tapak-tapak di bagian Barat diduga menyebabkan tingginya pencucian tanah sehingga berdampak pada pertumbuhan dan perkembangan benih yang lebih kecil pada populasipopulasi tapak tersebut. Hal ini dapat diamati dari hasil analisis kesuburan tanah (Tabel 2) yang menunjukkan tapak-tapak populasi di bagian Barat (seperti populasi dari Pulau Sumatera) relatif mengandung unsur-unsur yang dibutuhkan tanaman lebih rendah, seperti N, P, K, Ca, dan Mg. Pada jenis-jenis conifer, tingginya tingkat pencucian tanah akibat curah hujan yang tinggi dalam hubungannya dengan ukuran kerucut telah dilaporkan oleh Roy et al. (2004) pada Pinus roxburghii dan Rawat dan Bakshi (2011) pada Pinus wallichia$n a$. Suhu tahunan makin tinggi juga berpengaruh terhadap panjang benih dan juga rata-rata waktu berkecambah benih yang semakin cepat. Hal yang sama juga dilaporkan oleh Jian-xun et al. (2005) pada jenis Picea asperata yang menyatakan korelasi positif antara garis lintang dan suhu rata-rata tahunan dengan panjang benih. Suhu secara langsung berperan terhadap perkembangan benih, dimana peningkatan suhu pada batas optimal untuk perkembangan benih akan meningkatkan jumlah benih berisi dan laju produksi bahan kering pada benih (Kobata dan Uemuki, 2004; Gao et al., 2012).

\section{Koefisien keragaman}

Koefisien keragaman genotipe untuk semua parameter buah, benih, dan bibit jabon putih ditemukan lebih tinggi daripada koefisien keragaman lingkungan. Besaran keragaman galat relatif lebih rendah daripada keragaman genotipe untuk semua karakter, sedangkan koefisien keragaman fenotipe dan genotipe sangat dekat satu dengan yang lainnya untuk semua karakter. Begitu pula dengan heritabilitas yang berada pada kisaran $52-99 \%$. Hal ini memberi indikasi bahwa komponen genotipe berkontribusi sangat besar terhadap total keragaman untuk karakterkarakter tersebut; yaitu hampir semua keragaman yang diamati dalam fenotipe untuk karakterkarakter tersebut dikendalikan faktor genetik dari pada faktor non genetik.

Sebagian besar karakter morfologi buah dan benih jabon putih dikendalikan sangat kuat oleh faktor genotipe. Hasil penelitian Khalil (1974) juga memberi indikasi bahwa faktor lingkungan yang bervariasi antar lokasi dan populasi dalam suatu lokasi mempunyai pengaruh yang kecil terhadap karakter morfolofi buah Picea glauca. Hasil yang sama juga dilaporkan pada jenis Tectona grandis (Jayasankar et al., 1999; Sivakumar et al., 2002), Dalbergia sissoo (Gera et al., 2000), Juniperus procera (Mamo et al., 2006), dan Cordia africana (Loha et al., 2006). Keragaman morfologi benih dan bibit yang disebabkan keragaman genetik ini memberi indikasi cakupan yang luas untuk seleksi.

Nilai heritabilitas yang tinggi yang berpasangan dengan nilai kemajuan genetik yang tinggi ditunjukkan oleh karakter berat buah, daya berkecambah, kecepatan berkecambah, tinggi bibit dan indeks kekokohan bibit. Karakter-karakter tersebut mempunyai nilai genetik yang tinggi dan dapat digunakan sebagai kriteria untuk seleksi populasi dalam hubungnya dengan morfofisiologi benih dan bibit jabon. Nilai heritabilitas berguna sebagai indikator yang dapat digunakan untuk seleksi satu atau lebih karakter (Namkoong et al., 1966), namun bila nilai heritabilitasnya tinggi tetapi kemajuan genetiknya rendah dapat diartikan bahwa pengaruh genetik non-additive lebih besar dari pada pengaruh genetik additive sehingga karakter tersebut tidak dapat digunakan sebagai kriteria seleksi yang baik (Rawat dan Bakshi, 2011). Jonhnson et al. (1995) menyatakan bahwa karakter dengan nilai heritabilitas yang tinggi yang diikuti dengan kemajuan genetik tinggi dapat digunakan untuk memilih populasi terbaik.

\section{KESIMPULAN DAN SARAN}

Jabon putih mempunyai sebaran tempat tumbuh yang sangat luas dan kisaran kondisi tapak secara alami yang cukup beragam. Jenis ini dijumpai tumbuh baik pada ketinggian tempat 23-628 m dpl, dengan kisaran $\mathrm{pH}$ tanah 4,4-6,7 
(sangan masam hingga netral), dan tingkat kesuburan rendah hingga tinggi. Karakteristik morfofisiologi benih dan bibit antar populasi juga sangat beragam. Sebagian besar karakter benih dan bibit yang diamati tidak berkorelasi dengan faktor-faktor geoklimat. Komponen genotipe berkontribusi sangat besar terhadap total keragaman untuk karakter-karakter morfofisiologi buah, benih dan bibit jabon putih. Nilai heritabilitas pada semua karakter menunjukkan nilai yang tinggi. Karakter berat buah, daya berkecambah, kecepatan berkecambah, tinggi dan indeks kekokohan bibit memiliki nilai heritabilitas tertinggi dan diikuti dengan nilai kemajuan genetik tinggi sehingga dapat dijadikan indikator penting untuk pemilihan populasi terbaik.

\section{DAFTAR PUSTAKA}

Acharyya, S., Rathore, D.S., Kumar, H.K.S., \& Panda, N. 2011. Screening of Anthocephalus cadamba (Roxb.) Miq. Root for Antimicrobial and anthelmintic activities. International Journal of Research in Pharmaceutical and Biomedical Sciences 2(1): 297-300.

Bhattacharya, A.K., Lakhari, A.K., \& Basu, R.N. (1991). Improvement of germinability of Eucalyptus sp. by pre germination treatments. Indian Journal of Forests 117: 661-663.

Bonner, F.T., Fozzo, J.A., Elam, W.W., \& Land, S.B. Jr. (1994). Tree seed technology training course. Instructors manual. Southern Forest Experiment Station. US Department Agriculture.

Devagiri, G.M. (1997). Evaluation of seed source variation in seed and seedling traits in Dalbergia sissoo Roxb. Unpublished Ph.d. Thesis, Forest Research Institute University, Dehra Dun, India.

Dunlap, J.R., \& Barnett, J.P. (1984). Influence of seed size germination and early development of loblly pine (Pinus taeda L.) Germinants. Canadian Journal of Forest Research 13: 4044.

Edmond, J.B., \& Drapala, W.J. (1985). The effects of temperature, sand and soil, and acetone on germination of okra seed. Proc. of the American Society for Horticultural Science 71: 428-434.

Gao S., Wang J., Zhang, Z., Dong, G., \& Guo, J. (2012). Seed production, mass, germinability, and subsequent seedling growth responses to parental warming environment in Leymus chinensis. Crop and Pasture Science 63(1): 8794.
Gera, M., Gera, N., \& Ginwal, H.S. (2000). Seed trait variations in Dalbergia sissoo Roxb. Seed Science and Technology 28: 467-475.

Ghildiyal, S.K., Sharma, C.M., \& Gairola, S. (2009). Additive genetic variation in seedling growth and biomass of fourteen Pinus roxburghii provenances from Garhwal Himalaya. Indian Journal of Science and Technology 2(1): 3745.

Harper J.L., Lovell P.H., \& Moore K.G. (1970). The shapes and sizes of seeds. Annual Review of Ecology and Systematics 11:327-356.

ISTA (International Seed Testing Association). (2010). International rules for seed testing edition 2010. The International Seed Testing Association. Bassersdorf. CH-Switzerland.

Jayasankar, S., Babu, L.C., Sudhakar, K., \& Unnithan, V.K.G. (1999). Provenance variation in seed and germination characteristics of teak (Tectona grandis L.F.). Seed Science and Technology 27: 131-139.

Jiang-xun, L., Xiao-lu, Z., \& Wan-chun, G. (2009). Biogeographic differences in cone, needle and seed morphology among natural Picea asperata populations in Western China. Forestry Study in China 7(2): 1-6.

Johnson, H.W., Robinson, H.F., \& Comstock, R.F. (1955). Estimates of genetic and environmental variability in Soyabean. Agronomy Journal 47: 314-318

Kallio, M.H., Krisnawati, H., Rohadi, D., \& Kanninen, M. (2011). Mahogany and kadam planting farmers in South Kalimantan: The link between silvicultural activity and stand quality. Small-scale Forestry 10: 115-132.

Kandya, A.K. (1978). Relationship among seed weight and various growth factors in Pinus ocarpa Schiede Seedlings. Indian Journal of Forests 104: 561-567.

Kartawinata, K. (1994). The use of secondary forest species in rehabilitation of degraded forest lands. Journal of Tropical Forest Science 7(1): 76-86.

Khalik, M.A.K. (1974). Genetics of cone morphology in white spruce (Picea glauca). Canadian Journal Botany 52:15-21.

Kotaba, T., \& Uemuki, N. (2004). High tempetures during the grain-filling period do not reduce the potential grain dry matter increase of rice. Agronomy Journal 96: 406-414.

Krisnawati, H., Kallio, M., \& Kanninen, M. (2011). Anthocephalus cadamba Miq. Ekologi, Silvikultur dan Produktivitas. Bogor, Indonesia: Center for International Forestry Research. 
Lester, D.T. (1969). Variation in cone morphology of balsam fir (Abies balsamea). Rhodora 70(781): 83-94

Lichtenthaler, H.K. (1987). Chlorophylls and carotenoids: Pigments of photosynthetic biomembranes. Methods Enzymology 148: 350-382.

Loha, A., Tigabu, M., Teketay, D., Lundkvist, K., \& Fries, A. (2006). Provenance variation in seed morphometric traits, germination and seedling growth of Cordia africana Lam. New Forests 32: 71-86.

LPT (Lembaga Penelitian Tanah). (1979). Penuntun analisa fisika tanah. Bogor: Lembaga Penelitian Tanah

Maguire, J.D. (1962). Speed of germination - aid in selection and evaluation for seedling emergence and vigor. Crop Science 2:176-177.

Maheshwari P., \& Konar R.N. (1971). Pinus botanical monograph No. 7, CSIR, New Delhi pp. 1-130.

Mamo, N., Mihretu, M., Fekadu, M., Tigabu, M., \& Teketay, D. (2006). Variation in seed and germination characteristics among juniperus procera populations in Ethiopia. Forest Ecology and Management 22 5: 320-327.

Marshall, P.E., Kozlowski T.T. (1976). Compositional changes in cotyledons of woody angiosperms. Canadian Journal Botany 54: 2473-2477.

Martawijaya, A., Kartasujana, I., Mandang, Y.I., Prawira, S.A., \& Kadir, K. (1989). Atlas Kayu Indonesia Jilid II. Bogor, Indonesia: Pusat Penelitian dan Pengembangan Hasil Hutan.

Mishra, R.P., \& Siddique, L. (2011). Antibacterial properties of Anthocephalus cadamba fruits. Asian Journal of Plant Science and Research 1(2):1-7.

Mondal, S., Dash, G.K., \& Acharyya, S. (2009). Analgesic, anti-inflammatory and antipyretic studies of Neolamarckia cadamba barks. Journal of Pharmacy Research 2(6): 11331136 .

Mughal, A.H., \& Thapliyal, R.C. (2012). Provenance variation in cone and seed characteristics of Cedrus deodara (D.DON) G.DON in Jammu and Kashmir. Forestry Study in China 14(3): 193-199.

Mukherjee, S. (2005). Studies on provenance variation in cone, seed and seedling characteristics of Pinus roxburghii Sarg. Unpublished Ph.D. Thesis, Forest Research Institute, Deemed University Dehra Dun.

Namkoong, G., Synder, E.B., \& Stonecypher, R.W. (1966). Heratibility and gain concepts for evaluating breeding system such as seedling orchards. Silvae Genetica 15: 76-84.

Pathak, P.S., Debroy, R., \& Rai, P. (1984). Autecology of Leucaena leucocephala (Lam) de Wit. seed polymorphism and germination. Tropical Ecology 15(1, 2):1-10.

Phillips P.D., Yasman I., Brash T.E., \& van Gardingen P.R. (2002). Grouping tree species for analysis of forest data in Kalimantan (Indonesian Borneo). Forest Ecology and Management 157: 205216.

Pusat Penelitian Tanah. (1983). Jenis dan macam tanah di Indonesia untuk keperluan survai dan pemetaan tanah daerah transmigrasi. Bogor: Pusat Penelitian Tanah.

Rawat, K., \& Bakshi, M. (2011). Provenance variation in cone, seed and seedling characteristics in natural populations of Pinus wallichiana A.B. Jacks (blue pine) in India. Annals of Forest Research 54(1): 39-55.

Roy M.S., Thapliyal R.C., \& Phartyal S.S. (2004). Seed source variation in cone, seed and seedling characteristics across the Natural Distribution of Himalayan low level pine Pinus roxburghii sarg. Silvae Genetica 53(3): 116-122.

Sagwal, W.S. (1984). Studies on seed production from individual cones of chir pine (Pinus roxburghii Sarg.). Indian Journal of Forests 7(1): 4-6.

Salazar, R. (1989). Genetic variation of 16 provenances of Acacia mangium at nursery level on Turrialba. Costa Rica. Commonwealth Forest Review 68(4): 263-272.

Sanchez, A.C., De Smedt, S., Haqa, N., \& Samson, R. (2011). Variation in baobab seedling morphology and its implications for selecting superior planting material. Scientia Horticulturae 130: 109-117.

Seghal, R.N., Chauchan, S.K., \& Khosla, P.K. (1994). Variation in cone, seed and nursery characters in high resin yielding trees selected in Himachal Pradesh. Indian Journal of Forests 17: 105-111.

Shukla, R.P., \& Ramakrishnan, P.S. (1986). Architecture and growth strategies of tropical trees in relation to successional status. Journal of Ecology 74: 33-46.

Singh, O. (1998). Seed maturity indices in silver fir (Abies pindrow Spach.). Indian Journal of Forests 124(3): 243-246.

Sivakumar, V., Parthiban, K.T., Singh, B.G., Gnanambal, V.S., Anandalakshmi, R., \& Geetha S. (2002). Variability in drupe characters and their relationship on seed 
germination in teak (Tectona grandis L.F.). Silvae Genetics 51:232-237.

Sneizko, R.A., \& Stewart, H.T.L. (1989). Range wide provenance variation in growth and nutrition of Acacia albida seedlings propagated in Zimbabwe. Forest Ecology and Management 27(3-4): 179-197.

Soerianegara, I., \& Lemmens, R.H.M.J. (1993). Plant Resources of South-east Asia 5 (1): Timber Trees: Major Commercial Timbers. Wageningen, Netherlands: Pudoc Scientific Publishers.

Stephan, B.R. (1974). Geographical variation in Pinus strobus on the basis of preliminary results of field trials in lower saxony. Silvae Genetica 23(6): 214-220.

Suganda, H., Rachman A., \& Sutono, S. (2006). Petunjuk pengambilan contoh tanah. Balai Besar Penelitian dan Pengembangan Sumberdaya Lahan Pertanian. p 25-34.
Takuathung, C.N., Pipatwattanakul, D., \& Bhumibhamon, S. (2012). Provenance variation in seed morphometric traits and growth performance of Senna siamea (Lam.) Erwin et Barneby at Lad Krating Plantation, Chachoengsao Province, Thailand. Kasetsart Journal (Nat. Sci.) 46: 394-407.

Wong, K.M. (1989). Rubiaceae. In: F.S.P.Ng(ed.), Tree Flora of Malaya: 381-382. A Manual for Foresters, Vol. 4. FRIM and Ministry of Primary Industries, Malaysia.

Zheng, Y.I., Sun, W.B., Zhou, Y., \& Coombs, D. 2009. Variation in seed and seedling traits among natural populations of Trigonobalanus doichangesis (A. Camus) forman (Fagaceae), a rare and endangered plant in Southwest China. New Forests 37: 285-294. 